\title{
Analysis of Acoustic Second-Harmonic Generation in Alternating Multilayered Structure with Closed Defect at Interlayer Interface
}

by

Yosuke IsHir* and Tadaharu ADAchi*

The one-dimensional longitudinal wave propagation in the layering direction in an alternating multilayered structure with nonlinear spring-type interfaces is analyzed theoretically to study the second-harmonic generation behavior due to the presence of closed defects at interlayer interfaces. The structure consists of alternating linear elastic layers and is surrounded by two linear elastic semi-infinite media. The layers as well as semi-infinite media are bonded to each other by nonlinear spring-type interfaces possessing identical linear interfacial stiffness and different quadratic nonlinearity to model closed defects such as delaminations and cracks. On the assumption of weak nonlinearity, the second-harmonic amplitudes of the reflected and transmitted waves when a monochromatic longitudinal wave impinges perpendicularly on the structure are derived by combining a perturbation approach with the transfer-matrix method. It is found that the wave propagation characteristics are governed by five non-dimensional parameters: the non-dimensional frequency, the number of interfaces (layers), the acoustic impedance ratio between neighboring media, the stiffness ratio between the interface and the layer, and the ratio of times of flight between neighboring layers. The second-harmonic amplitudes due to a single nonlinear interface are shown to be influenced remarkably by the fundamental frequency as well as the position of nonlinear interface in the multilayered structure. These features are successfully explained by using the pass and stop band characteristics of the layered structure and the spatial distributions of the fundamental and the second-harmonic displacements inside the structure.

\section{Key words:}

Second-harmonic generation, Multilayered structure, Closed defect, Nonlinear spring-type interface, Perturbation analysis, Transfer-matrix method, Stop band

1 緒言

積層構造はビルや橋梁といった大型構造物における免 振装置，電子工学分野における積層コンデンサ，航空機 や宇宙機構造における繊維強化積層複合材料など, 多種 多様な工学分野で実用されている，そのため，積層構造 中の弾性波伝搬挙動を明らかにすることは，動的荷重に 対する構造設計や超音波非破壞検查の観点から極めて重 要である.

特に非破壊検查の分野では，層間界面の健全性低下が 構造や製品の機能低下や強度低下に直結するため, 層間 に発生した欠陥（はく離やき裂など）の検查が重点的に 行われている。このような検査には, 超音波を積層構造 に入射し欠宿部からの反射波を測定寸ることで久陷検出 を行うパルス・エコー法が一般的に用いられている ${ }^{1)}$.こ の手法は, 久陥が十分に開口し超音波が明示的に反射さ れるような場合には有効であるが，一方で外的負荷や残 留応力などの影響により欠皕が閉口しているような場合 には欠陥部での波動散乱が著しく弱くなるため検出が困 難になる。

このような閉口欠陥に対して久陥を開口させるほどの
大振幅超音波を入射すると, き裂面の非線形な開閉口挙 動に起因して高次高調波 (入射周波数の整数倍周波数を 有する信号）が発生する。このような現象は接触型音響 非線形性と呼ばれており, 久陥部で発生した高調波信号 を測定することで従来法では捉えられない閉口欠陥を高 感度に検出できる可能性があるとして近年注目を集めて いる.

これまでに, 単一の固体間接触界面における高次高調

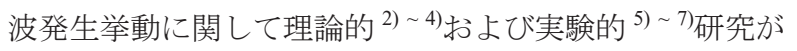
数多く報告されている. 特に, 送信周波数の二倍周波数 を有する二次高調波信号の発生挙動は, 接触界面を二次 の非線形スプリング界面とすることで実験結果を良好に 再現できることが明らかにされている ${ }^{4)}$.また，Yan ら ${ }^{8)}$ は，このようなモデル化を三層構造の層間界面 (二重界 面問題）に適用し，二次高調波発生挙動の理論的検討お よび測定值との比較を行っている.

より一般的な多重界面を有する積層構造に関しても, 非線形スプリング界面モデルに基づく二次高調波発生挙 動の基礎的研究が報告されている9) 11). その結果, 単一 界面問題においては二次高調波振幅が周波数に対して単

$\dagger$ 原稿受理 平成30年4月29日 Received Apr. 29, 2018 @2019 The Society of Materials Science, Japan

* 正 会員 豊橋技術科学大学 機械工学系 $\overline{7} 441-8580$ 豊橋市天伯町雲雀ヶ丘

Department of Mechanical Engineering, Toyohashi University of Technology, Tempaku-cho, Toyohashi, 441-8580. 
調増加するのに対し，多重界面問題では二次高調波振幅 が複雑な周波数依存性を示すことが明らかにされている. これは界面で発生した高調波が各界面で反射・透過を繰 り返しながら積層構造を伝搬することに起因している.

上記の先行研究 9) 11) では, 多重界面問題の最も単純な 場合として，非線形スプリング界面を有する積層構造の すべての層が同じ音響特性を有すると仮定している。一 方で，工学分野では異種材料から成る積層構造が実用さ れることが多く，このような構造中における二次高調波 発生挙動を解明することは構造健全性や信頼性を確保す るうえで重要な課題である，そこで，本研究では，異な る二種類の線形弾性層が交互に積層された構造を考え, 層間に発生した閉口欠陥を非線形スプリング界面でモデ ル化する．このときの積層方向に関する 1 次元縦波伝搬 に伴う二次高調波発生挙動の解明および閉口欠陷の非破 壊検出のための知見を得ることを目的として，摂動法お よび伝達マトリクス法 ${ }^{12)}$ 用いた理論的検討を行った。

\section{2 定式化}

\section{$2 \cdot 1$ 支配方程式}

Fig. 1 に示すような積層構造において, 積層方向 $(x$ 方 向）に関する 1 次元の縦波伝搬問題を考える.

積層構造は二種類の線形弾性層 “Layer $0 ”$ (密度 $\rho_{0}$, 音 速 $c_{0}$, 厚さ $h_{0}$ ) および “Layer 1 ” (密度 $\rho_{1}$, 音速 $c_{1}$, 厚さ $h_{1}$ ） が合計 $N-1$ 層交互積層されており, それが Layer 1 と同じ材料特性の半無限媒質 $\left(x<X_{1}\right.$ および $\left.x>X_{N}\right)$ に挟 まれている，そして， $x=X_{m}(m=1,2, \ldots, N)$ に位置する 各媒質間の界面をスプリング界面でモデル化する。なお 本研究では，隣接する媒質が必ず異なる材質を有するよ うに，界面数 $N$ を偶数と仮定する.

位置 $x$ および時間 $t$ における縦波の変位を $u(x, t)$ とする と, $u$ は各媒質内で以下の波動方程式を満たす.

$$
\frac{\partial^{2} u}{\partial t^{2}}=c_{\alpha}^{2} \frac{\partial^{2} u}{\partial x^{2}}
$$

ここで， $x$ が Layer 0 内に位置する場合は $\alpha=0$ であり， Layer 1 および半無限媒質内の場合は $\alpha=1$ である.また, 応力 $\sigma(x, t)$ は次式で与えられる.

$$
\sigma(x, t)=\rho_{\alpha} c_{\alpha}^{2} \frac{\partial u}{\partial x}
$$

第 1 章でも述べたように，固体間接触界面における二 次高調波発生挙動は二次の非線形スプリング界面により 良好に再現することができる ${ }^{4)}$.したがって，本研究では

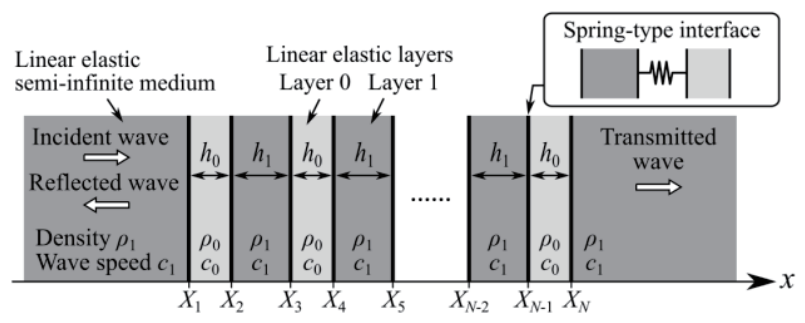

Fig. 1 Computational model.
各界面における境界条件として次式を考える。

$$
\sigma\left(X_{m+}, t\right)=\sigma\left(X_{m-}, t\right)=K\left[1-\beta_{m} y_{m}(t)\right] y_{m}(t) .
$$

ここで，下付き添え字 “ $m+$ ” および “ $m-”$ は, $x$ が $x>X_{m}$ および $x<X_{m}$ から $X_{m}$ へ漸近するときの当該物理量の極限 值を表す．また， $K$ は線形界面剛性を表す． $K \rightarrow \infty$ は隣接 する二つの部材が完全接着（忘力と変位が連続）されて いる状態（ただし応力は有限值を取ると仮定）を表し， $K$ $=0$ は完全にはく離している状態（開口欠陥）を表す．各 部材が接着接合されており層間に縦波の波長よりも十分 薄い接着層が存在する場合や，部材間に閉口欠陥（部分 接触を有する界面）が存在する場合は $K$ が有限の值を取 る. 式(3)の $\beta_{m} \geq 0$ は $x=X_{m}$ に位置する界面の非線形性を 表すパラメータ（閉口欠陥の平衡時の部分接触状態に依 存）である. 界面に閉口欠陥が存在しない場合は $\beta_{m}=0$ となる. そして, $y_{m}(t)$ は界面両側における変位差 (界面の 間隙幅）を表し，次式で与えられる.

$$
y_{m}(t)=u\left(X_{m+}, t\right)-u\left(X_{m-}, t\right)
$$

閉口欠陷では微視的に見ると無数の突起同士が接触し ている状態であり, 接触圧力が増加するにつれて真実接 触面積が増加し見かけの界面剛性が高くなる. 式(3)は縦 波によるこのような剛性変化を表しており, 平衡状態 $\left(y_{m}=0\right)$ の閉口欠陥に縦波が入射するとき圧縮相 $\left(y_{m}<0\right)$ では界面の剛性が高くなり, 引張相 $\left(y_{m}>0\right)$ では剛性が低くなる. そのため, 単一周波数を有する正 弦波状の縦波が界面に入射すると，圧縮相と引張相で反 射・透過特性が異なるため, 反射波形や透過波形は正弦波 からひずんだ形となる。これは, 周波数スペクトルの観 点から言えば，直流成分や高次高調波成分が発生するこ とを示している.

なお，本研究では層間に閉口欠陥が存在し，それが線 形な波動伝搬特性にほとんど影響を及ぼさない（パル ス・エコー法などの線形波動特性に基づく検查法では欠 陥を検出できない）状況を想定している．また，Fig. 1 に 示すように $N$ 個の界面はすべて二種類の異なる媒質の間 にあることから, 以下ではすべての界面が同じ線形剛性 $K$ $>0$ を有すると仮定する.

本研究では, 角周波数 $\omega=\omega_{0}$ の調和縦波が $x<X_{1}$ から 積層構造に入射し， $x<X_{1}$ に反射波， $x>X_{N}$ に透過波が生 じる状況を考える (Fig. 1 参照)，前述のように，界面に 縦波が入射すると基本波成分 $\left(\omega=\omega_{0}\right)$ が反射・透過する のと同時に, 式(3)の界面非線形性（界面剛性の間隙幅依 存性）に起因して直流成分 $(\omega=0)$ および高次高調波成 分 $\left(\omega=2 \omega_{0}, 3 \omega_{0}, \ldots\right)$ が発生する. そして, これらの信 号は積層構造の各界面で反射・透過を繰り返した後, $x<X_{1}$ および $x>X_{N}$ 方向に伝搬する. したがって，反射波およ び透過波には一般に $\omega=0, \omega_{0}, 2 \omega_{0}, 3 \omega_{0}, \ldots$ の周波数 成分が含まれる。その中でも本研究では, 二次高調波成 
分 $\left(\omega=2 \omega_{0}\right)$ に着目し, 反射波・透過波に含まれる二次 高調波振幅の入射周波数依存性について検討する。

\section{$2 \cdot 2$ 摂動法による支配方程式の線形化}

変位の基本波成分を $u_{1}$, 二次高調波成分を $u_{2}$ として, 次式を仮定する。

$u_{1}(x, t)=\operatorname{Re}\left[U_{1}(x) \exp \left(-\mathrm{i} \omega_{0} t\right)\right]$,

$u_{2}(x, t)=\operatorname{Re}\left[U_{2}(x) \exp \left(-2 \mathrm{i} \omega_{0} t\right)\right]$.

ここで $\mathrm{i}$ は虚数単位である. 非線形性による寄与が十分小 さい（入射波振幅を $A_{\text {in }}$ としたとき $\max _{m}\left[\beta_{m}\right] A_{\text {in }}$ が十分小 さい) と仮定し, 式(1)-(4)に摂動法を適用すると ${ }^{10)}, U_{1}(x)$ および $U_{2}(x)$ の満たすべき式として次式が得られる。

基本波成分:

$\frac{\mathrm{d}^{2} U_{1}}{\mathrm{~d} x^{2}}+\frac{\omega_{0}^{2}}{c_{\alpha}^{2}} U_{1}=0$,

$\rho_{1} c_{1}^{2} \frac{\mathrm{d} U_{1}}{\mathrm{~d} x}\left(X_{m-}\right)=\rho_{0} c_{0}^{2} \frac{\mathrm{d} U_{1}}{\mathrm{~d} x}\left(X_{m+}\right)=K Y_{1 m}$, $(m=1,3, \ldots, N-1)$

$\rho_{0} c_{0}^{2} \frac{\mathrm{d} U_{1}}{\mathrm{~d} x}\left(X_{m-}\right)=\rho_{1} c_{1}^{2} \frac{\mathrm{d} U_{1}}{\mathrm{~d} x}\left(X_{m+}\right)=K Y_{1 m}$, $(m=2,4, \ldots, N)$

$Y_{1 m}=U_{1}\left(X_{m+}\right)-U_{1}\left(X_{m-}\right)$.

二次高調波成分:

$\frac{\mathrm{d}^{2} U_{2}}{\mathrm{~d} x^{2}}+\frac{\left(2 \omega_{0}\right)^{2}}{c_{\alpha}^{2}} U_{2}=0$,

$\rho_{1} c_{1}^{2} \frac{\mathrm{d} U_{2}}{\mathrm{~d} x}\left(X_{m-}\right)=\rho_{0} c_{0}^{2} \frac{\mathrm{d} U_{2}}{\mathrm{~d} x}\left(X_{m+}\right)$

$$
=K Y_{2 m}-\frac{1}{2} \beta_{m} K Y_{1 m}^{2}
$$

$$
(m=1,3, \ldots, N-1),
$$

$$
\begin{aligned}
\rho_{0} c_{0}^{2} \frac{\mathrm{d} U_{2}}{\mathrm{~d} x}\left(X_{m-}\right) & =\rho_{1} c_{1}^{2} \frac{\mathrm{d} U_{2}}{\mathrm{~d} x}\left(X_{m+}\right) \\
& =K Y_{2 m}-\frac{1}{2} \beta_{m} K Y_{1 m}^{2}
\end{aligned}
$$$$
(m=2,4, \ldots, N)
$$

$Y_{2 m}=U_{2}\left(X_{m+}\right)-U_{2}\left(X_{m-}\right)$.

式(7)-(14)は線形方程式となっているため, これらの式 から二次高調波の変位場 $U_{2}(x)$ を解析的に求めることが できる，その計算順序として，まず初めに式(7)-(10)を解 くことで基本波の変位場 $U_{1}(x)$ を求める. 次に, 求めた $U_{1}(x)$ と式(10)より, 基本波変位による各界面の間隙幅 $Y_{1 m}$ を計算する。 そして，得られた $Y_{1 m}$ を用いて式(11)-(14) を解き $U_{2}(x)$ を求める。これらの計算過程の詳細を以下 に説明する

\section{$2 \cdot 3$ 基本波 $\left(\omega=\omega_{0}\right)$ の伝搬問題}

ここでは，周期構造の波動伝搬問題によく用いられる 伝達マトリクス法 ${ }^{12)}$ を用いて，基本波の振幅反射・透過 率および界面間隙幅 $Y_{1 m}$ を求める.

式(7)は 1 次元へルムホルツ方程式であり, その一般解 $U_{1}(x)$ は， $x$ の正方向に伝搬する縦波 $U_{1 \mathrm{~F}}(x)$ と負方向に伝 搬する縦波 $U_{1 \mathrm{~B}}(x)$ の重ね合わせとして, $U_{1}(x)=U_{1 \mathrm{~F}}(x)+$ $U_{1 \mathrm{~B}}(x)=C_{\mathrm{F}} \exp \left(\mathrm{i} \omega_{0} x / c_{\alpha}\right)+C_{\mathrm{B}} \exp \left(-\mathrm{i} \omega_{0} x / c_{\alpha}\right) \quad\left(C_{\mathrm{F}}, C_{\mathrm{B}}\right.$ : 任意
定数) と表される.そこで, 変位ベクトルを $\mathbf{d}_{1}(x) \equiv\left(U_{1 \mathrm{~F}}(x)\right.$, $\left.U_{1 \mathrm{~B}}(x)\right)^{\mathrm{T}}$ と定義すると, 式(8)および(9)より, 各界面両側 における変位は次式のように関係付けられる。

$$
\mathbf{d}_{1}\left(X_{m+}\right)= \begin{cases}\mathbf{S}_{10}(\Omega) \mathbf{d}_{1}\left(X_{m-}\right), & m=1,3, \ldots, N-1, \\ \mathbf{S}_{01}(\Omega) \mathbf{d}_{1}\left(X_{m-}\right), & m=2,4, \ldots, N .\end{cases}
$$

ここで, $\mathbf{S}_{10}(\Omega)$ および $\mathbf{S}_{01}(\Omega)$ は Layer 1（または半無限媒 質）-Layer 0 界面および Layer 0-Layer 1（または半無限 媒質) 界面の散乱マトリクスを表し，次式で与えられる。

$$
\begin{aligned}
& \mathbf{S}_{10}(\Omega)=\frac{1}{2}\left[\begin{array}{cc}
1+\zeta+\mathrm{i} \Lambda \Omega \zeta & 1-\zeta-\mathrm{i} \Lambda \Omega \zeta \\
1-\zeta+\mathrm{i} \Lambda \Omega \zeta & 1+\zeta-\mathrm{i} \Lambda \Omega \zeta
\end{array}\right], \\
& \mathbf{S}_{01}(\Omega)=\frac{1}{2}\left[\begin{array}{cc}
1+1 / \zeta+\mathrm{i} \Lambda \Omega & 1-1 / \zeta-\mathrm{i} \Lambda \Omega \\
1-1 / \zeta+\mathrm{i} \Lambda \Omega & 1+1 / \zeta-\mathrm{i} \Lambda \Omega
\end{array}\right] \\
& \text { ここで,} \\
& \Omega \equiv \frac{\omega_{0} h_{0}}{c_{0}}, \quad \Lambda \equiv \frac{\rho_{0} c_{0}^{2}}{K h_{0}}, \quad \zeta \equiv \frac{\rho_{1} c_{1}}{\rho_{0} c_{0}}
\end{aligned}
$$

である. 規格化基本周波数 $\Omega$ は Layer 0 における波長と厚

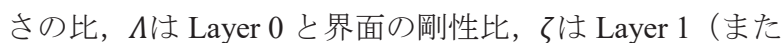
は半無限媒質）と Layer 0 の音響インピーダンス $\left(\rho_{1} c_{1}\right.$ お よび $\left.\rho_{0} c_{0}\right)$ の比を表す無次元パラメータである.

次に, 前述のように $U_{1 \mathrm{~F}}(x) \sim \exp \left(\mathrm{i} \omega_{0} x / c_{\alpha}\right)$ および $U_{1 \mathrm{~B}}(x) \sim$ $\exp \left(-\mathrm{i} \omega_{0} x / c_{\alpha}\right)$ となることを考慮すると, 各層内の両端に おける変位は次式のように関係付けられる.

$$
\mathbf{d}_{1}\left(X_{(m+1)-}\right)=\left\{\begin{array}{l}
\mathbf{P}_{0}(\Omega) \mathbf{d}_{1}\left(X_{m+}\right), m=1,3, \ldots, N-1, \\
\mathbf{P}_{1}(\Omega) \mathbf{d}_{1}\left(X_{m+}\right), m=2,4, \ldots, N-2 .
\end{array}\right.
$$

ここで, $\mathbf{P}_{0}(\Omega)$ および $\mathbf{P}_{1}(\Omega)$ は Layer 0 および Layer 1 のプ ロパゲータマトリクスを表し，次式で与えられる.

$$
\begin{aligned}
& \mathbf{P}_{0}(\Omega)=\left[\begin{array}{cc}
\exp (\mathrm{i} \Omega) & 0 \\
0 & \exp (-\mathrm{i} \Omega)
\end{array}\right] \\
& \mathbf{P}_{1}(\Omega)=\left[\begin{array}{cc}
\exp (\mathrm{i} \Omega \eta) & 0 \\
0 & \exp (-\mathrm{i} \Omega \eta)
\end{array}\right] .
\end{aligned}
$$

ここで,

$$
\eta \equiv \frac{h_{1} c_{0}}{h_{0} c_{1}}=\frac{h_{1} / c_{1}}{h_{0} / c_{0}}
$$

は縦波が Layer 0 および Layer 1 を伝搬するために要する 時間の比を表す無次元パラメータである。

式(15)および(19)を組み合わせることで, 積層構造の両 端における変位の関係は次式のようになる。

$$
\mathbf{d}_{1}\left(X_{N+}\right)=\mathbf{L}(\Omega) \mathbf{d}_{1}\left(X_{1-}\right) .
$$

ここで，Lはグローバル伝達マトリクスを表し，次式で 与えられる。

$$
\begin{aligned}
\mathbf{L}(\Omega) & \equiv\left[\begin{array}{ll}
L_{11}(\Omega) & L_{12}(\Omega) \\
L_{21}(\Omega) & L_{22}(\Omega)
\end{array}\right] \\
& =\mathbf{P}_{1}^{-1}(\Omega)\left[\mathbf{P}_{1}(\Omega) \mathbf{S}_{01}(\Omega) \mathbf{P}_{0}(\Omega) \mathbf{S}_{10}(\Omega)\right]^{\frac{N}{2}} \\
& =\mathbf{P}_{1}^{-1}(\Omega) \mathbf{H}^{\frac{N}{2}}(\Omega) .
\end{aligned}
$$

ここで， $\mathbf{H}(\Omega) \equiv \mathbf{P}_{1}(\Omega) \mathbf{S}_{01}(\Omega) \mathbf{P}_{0}(\Omega) \mathbf{S}_{10}(\Omega)$ である 
積層構造の左側 $\left(x<X_{1}\right)$ における変位場は入射波 (振 幅 $\left.A_{\text {in }}\right)$ と反射波の重ね合わせで表され，右側 $\left(x>X_{N}\right)$ は透過波で表されることから， $\mathbf{d}_{1}\left(X_{1-}\right)$ および $\mathbf{d}_{1}\left(X_{N+}\right)$ は 次式のように書くことができる.

$$
\begin{aligned}
& \mathbf{d}_{1}\left(X_{1-}\right)=\left(\begin{array}{c}
A_{\text {in }} \exp \left(\mathrm{i} \Omega \widehat{X_{1}}\right) \\
R(\Omega) A_{\text {in }} \exp \left(-\mathrm{i} \Omega \widehat{X_{1}}\right)
\end{array}\right), \\
& \mathbf{d}_{1}\left(X_{N+}\right)=\left(\begin{array}{c}
T(\Omega) A_{\text {in }} \exp \left(\mathrm{i} \Omega \widehat{X_{N}}\right) \\
0
\end{array}\right) .
\end{aligned}
$$

ここで, $\widehat{X_{q}} \equiv c_{0} X_{q} /\left(c_{1} h_{0}\right)(q=1, N)$ は規格化された左右 端界面の位置を表す。そして， $R(\Omega)$ および $T(\Omega)$ は基本 波の複素振幅反射率および複素振幅透過率を表し, 式 (23)-(26)より次式で与えられる。

$$
\begin{aligned}
& R(\Omega)=-\frac{L_{21}(\Omega)}{L_{22}(\Omega)} \exp \left(2 \mathrm{i} \Omega \widehat{X_{1}}\right), \\
& T(\Omega)=\left[L_{11}(\Omega)-\frac{L_{12}(\Omega) L_{21}(\Omega)}{L_{22}(\Omega)}\right] \exp \left[-\mathrm{i} \Omega\left(\widehat{X_{N}}-\widehat{X_{1}}\right)\right] .
\end{aligned}
$$

式(27)から求めた $R(\Omega)$ を式(25)に代入し,さらに式(15) および(19)を用いると, 基本波変位による界面間隙幅 (式 (10)）は次式のようになる.

$Y_{1 m}(\Omega)=U_{1 \mathrm{~F}}\left(X_{m+}\right)+U_{1 \mathrm{~B}}\left(X_{m+}\right)-U_{1 \mathrm{~F}}\left(X_{m-}\right)-U_{1 \mathrm{~B}}\left(X_{m-}\right)$

$=\mathbf{e}^{\mathrm{T}}\left[\mathbf{d}_{1}\left(X_{m+}\right)-\mathbf{d}_{1}\left(X_{m-}\right)\right]$

$=\left\{\begin{aligned} \mathbf{e}^{\mathrm{T}}\left[\mathbf{S}_{10}(\Omega)-\mathbf{I}\right] \mathbf{H}^{\frac{m-1}{2}}(\Omega) \mathbf{d}_{1}\left(X_{1-}\right), \_m & =1,3, \ldots, N-1, \\ \mathbf{e}^{\mathrm{T}}\left[\mathbf{S}_{01}(\Omega)-\mathbf{I}\right] \mathbf{P}_{0}(\Omega) \mathbf{S}_{10}(\Omega) \mathbf{H}^{\frac{m-2}{2}}(\Omega) \mathbf{d}_{1}\left(X_{1-}\right), \_m & =2,4, \ldots, N .\end{aligned}\right.$

ここで, $\mathbf{e} \equiv(1,1)^{\mathrm{T}}$ であり， I は $2 \times 2$ の単位行列を表す.

\section{$2 \cdot 4$ 二次高調波 $\left(\omega=2 \omega_{0}\right)$ の発生 ·伝搬問題}

次に, 式(29)より得られる $Y_{1 m}$ および式(11)-(14)に対し て再度伝達マトリクス法を適用することで, 反射波・透 過波に含まれる二次高調波振幅を求める.

$2 \cdot 3$ 節と同様に, 式(11)の一般解 $U_{2}(x)$ は $x$ の正方向に 伝搬する縦波 $U_{2 \mathrm{~F}}(x)$ と負方向に伝搬する縦波 $U_{2 \mathrm{~B}}(x)$ の重 ね合わせとして, $U_{2}(x)=U_{2 \mathrm{~F}}(x)+U_{2 \mathrm{~B}}(x)=E_{\mathrm{F}} \exp \left(2 \mathrm{i} \omega_{0} x / c_{\alpha}\right)$ $+E_{\mathrm{B}} \exp \left(-2 \mathrm{i} \omega_{0} x / c_{\alpha}\right)\left(E_{\mathrm{F}}, E_{\mathrm{B}}\right.$ : 任意定数 $)$ と表される. そ こで, 二次高調波の変位べクトルを $\mathbf{d}_{2}(x) \equiv\left(U_{2 \mathrm{~F}}(x)\right.$, $\left.U_{2 \mathrm{~B}}(x)\right)^{\mathrm{T}}$ と定義すると, 式(12)および(13)より，各界面両 側における变位は次式のように関係付けられる.

$$
\begin{aligned}
\mathbf{d}_{2}\left(X_{m+}\right) & =\frac{\beta_{m} Y_{1 m}^{2}(\Omega)}{4} \mathbf{e} \\
& + \begin{cases}\mathbf{S}_{10}(2 \Omega) \mathbf{d}_{2}\left(X_{m-}\right), & m=1,3, \ldots, N-1, \\
\mathbf{S}_{01}(2 \Omega) \mathbf{d}_{\mathbf{2}}\left(X_{m-}\right), & m=2,4, \ldots, N .\end{cases}
\end{aligned}
$$

なお，基本波の伝搬問題における境界条件（式(8)および (9)）と比較して，二次高調波のそれ（式(12)および(13)） は右辺に非同次項 $-\beta_{m} K Y_{1 m}^{2} / 2$ (二次高調波の駆動力）を 有する. そのため, 式(15)と比較して式(30)には右辺第一 項が新しく加わっている.

次に, $U_{2 \mathrm{~F}}(x) \sim \exp \left(2 \mathrm{i} \omega_{0} x / c_{\alpha}\right)$ および $U_{2 \mathrm{~B}}(x) \sim \exp (-$ $\left.2 \mathrm{i} \omega_{0} x / c_{\alpha}\right)$ となるため, 各層内の両端における二次高調波 の変位の関係は次式で与えられる.
$\mathbf{d}_{2}\left(X_{(m+1)-}\right)=\left\{\begin{array}{l}\mathbf{P}_{0}(2 \Omega) \mathbf{d}_{2}\left(X_{m+}\right), m=1,3, \ldots, N-1, \\ \mathbf{P}_{1}(2 \Omega) \mathbf{d}_{2}\left(X_{m+}\right), m=2,4, \ldots, N-2 .\end{array}\right.$

式(30)および(31)を組み合わせることで, 積層構造の両 端における二次高調波成分の関係は次式のようになる.

$\mathbf{d}_{2}\left(X_{N+}\right)=\mathbf{L}(2 \Omega) \mathbf{d}_{2}\left(X_{1-}\right)+\mathbf{b}(\Omega)$.

ここで,

$$
\begin{aligned}
& \mathbf{b}(\Omega) \equiv\left(\begin{array}{l}
b_{1}(\Omega) \\
b_{2}(\Omega)
\end{array}\right) \\
&=\frac{1}{4} \sum_{j=1}^{\frac{N}{2}} \mathbf{G}^{\frac{N}{2}-j}(2 \Omega)\left\{\beta_{2 j-1} Y_{1(2 j-1)}^{2}(\Omega) \mathbf{S}_{01}(2 \Omega) \mathbf{P}_{0}(2 \Omega)\right. \\
&\left.+\beta_{2 j} Y_{1(2 j)}^{2}(\Omega) \mathbf{I}\right\} \mathbf{e} .
\end{aligned}
$$

であり, $\mathbf{G}(\Omega) \equiv \mathbf{S}_{01}(\Omega) \mathbf{P}_{0}(\Omega) \mathbf{S}_{10}(\Omega) \mathbf{P}_{1}(\Omega)$ である.

非線形界面で発生した二次高調波は，各界面で反射・ 透過を繰り返した後，積層構造から外向きに伝搬するこ と（無限遠方からやってくる二次高調波はなし）を考慮

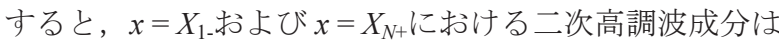
次式のように表すことができる.

$$
\begin{aligned}
& \mathbf{d}_{2}\left(X_{1-}\right)=\left(\begin{array}{c}
0 \\
A_{\mathrm{R} 2} \exp \left(-2 \mathrm{i} \Omega \widehat{X_{1}}\right)
\end{array}\right), \\
& \mathbf{d}_{2}\left(X_{N+}\right)=\left(\begin{array}{c}
A_{\mathrm{T} 2} \exp \left(2 \mathrm{i} \Omega \widehat{X_{N}}\right) \\
0
\end{array}\right) .
\end{aligned}
$$

ここで, $A_{\mathrm{R} 2}$ および $A_{\mathrm{T} 2}$ は反射波および透過波に含まれる 二次高調波振幅を表す。これらは, 式(34)および(35)を式 (32)に代入することにより，次式で与えられる.

$$
\begin{aligned}
& A_{\mathrm{R} 2}=-\frac{b_{2}(\Omega)}{L_{22}(2 \Omega)} \exp \left(2 \mathrm{i} \Omega \widehat{X_{1}}\right), \\
& A_{\mathrm{T} 2}=\left[b_{1}(\Omega)-\frac{b_{2}(\Omega) L_{12}(2 \Omega)}{L_{22}(2 \Omega)}\right] \exp \left(-2 \mathrm{i} \Omega \widehat{X_{N}}\right) .
\end{aligned}
$$$$
3 \text { 結果および考察 }
$$

\section{$3 \cdot 1$ 基本波の透過特性}

$3 \cdot 2$ 節で述べるように, 積層構造中の二次高調波伝搬 特性は基本波伝搬特性と密接に関係している. そのため, 本研究の目的である二次高調波伝搬特性の解明には, 基 本波伝搬特性の正しい理解が必要不可欠である。そこで, 本節では基本波の透過特性に着目し，振幅透過率 $|T(\Omega)|$ (式(28)）と規格化基本周波数 $\Omega$ の関係 (透過スペクトル) について検討する.

$2 \cdot 3$ 節より, 透過スペクトルは 4 個の無次元パラメー タ $N, \Lambda, \zeta, \eta$ にり特徵付けられる. 以下では, これ らの個々のパラメータが透過スペクトルに及ぼす影響 について考察する. なお, 振幅反射率と振幅透過率は互 いに独立ではなく, 常に $|R(\Omega)|^{2}+|T(\Omega)|^{2}=1$ (エネル ギ一保存則）となる。 そのため, 以下で得られる傾向は 反射スペクトル $(|R(\Omega)|$ と $\Omega$ の関係）に対してもほぼ同 様に成り立つものである.

$3 \cdot 1 \cdot 1$ 界面数 $N$ の影響 界面数を $N=6,10,20$ と 変化させ, その他のパラメータを $\Lambda=0.1, \zeta=1.5, \eta=1.0$ としたときの透過スペクトルをFig. 2(a)に示す. 
Fig. 2(a)の $\Omega / \pi=0.45,0.95,1.4,1.9,2.35$ 周辺で透過 率が低下寸る周波数帯（ストップバンド）が形成されて いる．これらは，各界面からの反射波の位相が整合し互 いに強め合う，いわゆるブラッグ反射が生じることに起 因している. 界面数が増加するとブラッグ反射の影響が より大きくなるため, ストップバンドにおける透過率の 低下も顕著になる。また，Fig. 2(a)のストップバンド以 外の周波数帯（パスバンド）では透過率が周波数に対し て振動し，積層数が増加するとその振動周期が短くなる

$3 \cdot 1 \cdot 2$ 音響インピーダンス比 $の$ 影響 次に, Layer 0 と Layer 1（または半無限媒質）の音響インピーダンス 比を $\zeta=1.0,1.5,2.0$ と変化させ，その他のパラメータを $N=20, \Lambda=0.1, \eta=1.0$ としたときの透過スペクトルを Fig. 2(b)に示す.

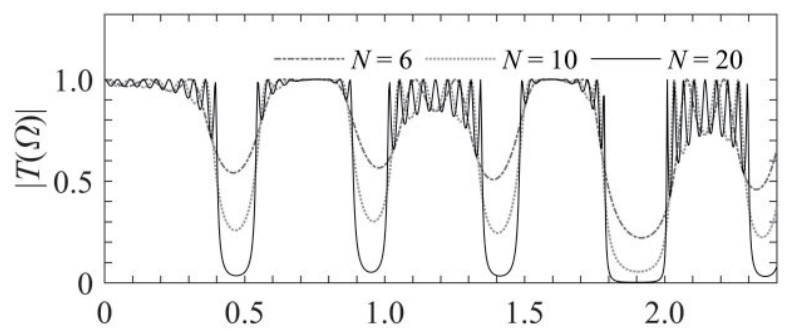

(a) Influence of $N$

$\Omega / \pi$

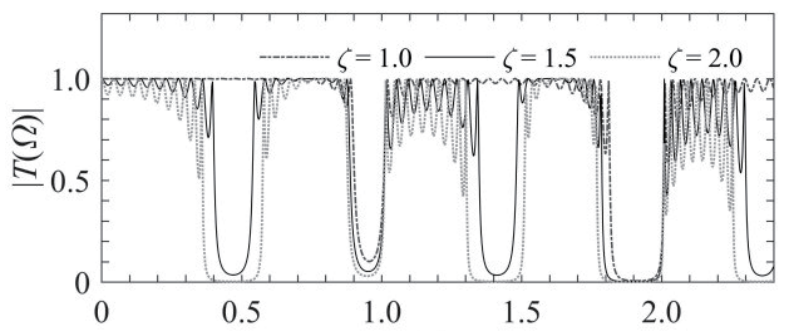

(b) Influence of $\zeta$

$\Omega / \pi$

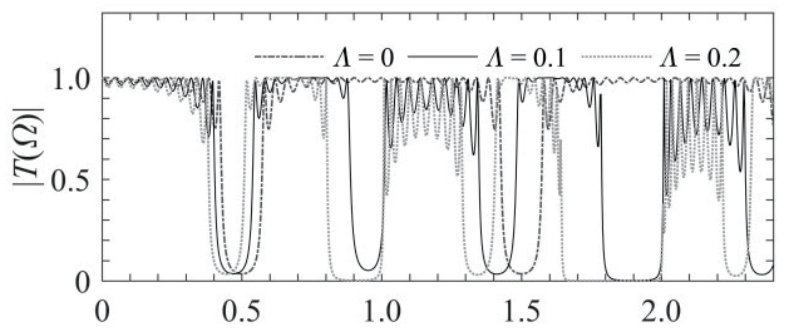

(c) Influence of $\Lambda$

$\Omega / \pi$

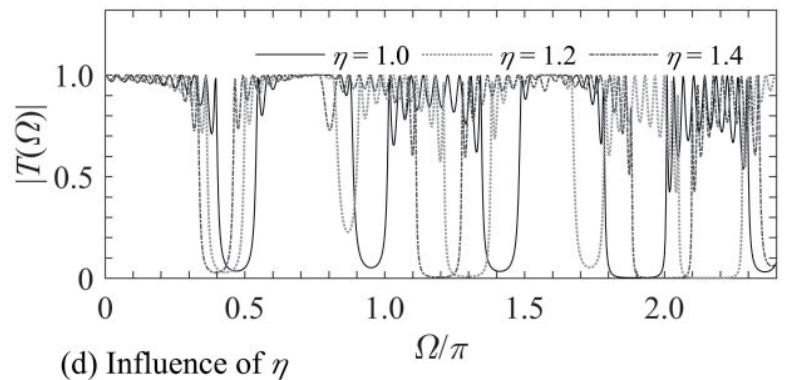

Fig. 2 Amplitude transmission spectra of fundamental-frequency component. (a) Influence of $N$ when $A=0.1, \zeta=1.5$ and $\eta=1.0$. (b) Influence of $\zeta$ when $N=20, \Lambda=0.1$ and $\eta=1.0$. (c) Influence of $\Lambda$ when $N=20, \zeta=1.5$ and $\eta=1.0$. (d) Influence of $\eta$ when $N=20, \Lambda=0.1$ and $\zeta=1.5$.
Fig. 2(b)の $\Omega / \pi=0.45 ， 1.4 ， 2.35$ 周辺において, $\zeta \neq 1$ のときにストップバンドが形成されており，らの増加と ともにバンド幅が広がりかつ透過率が低下している。こ れは，「が増加すると隣接する媒質のインピーダンス差 が大きくなり，個々の界面での反射・透過がより顕著に なるためである. 一方で, Fig. 2(b)の $\Omega / \pi=0.95$ および 1.9 周辺では, $\zeta=1$ (インピーダンス差なし) の場合で もストップバンドが発生している。 そして，上記と同様 の傾向（との増加に伴うバンド幅の拡張および透過率の 低下）が見られるが， $\Omega / \pi=0.45,1.4,2.35$ 周辺のスト ップバンドに比べて との影響は小さい.

ストップバンド形成の原因となる各界面での反射挙 動は，一般に隣接する媒質のインピーダンス差および界 面剛性 $K$ の有限性（ $\Lambda$ の有限性）の二つの因子によって 支配されるが，特別な場合として $\zeta=1$ のときには後者 のみによって反射が生じる．これより，Fig. 2(b)の $\Omega / \pi=$ 0.95 および 1.9 周辺のストップバンドは, 界面剛性の影 響が支配的なストップバンドであると考えられる。

$3 \cdot 1 \cdot 3$ Layer 0と界面の剛性比 1 影響 続いて, Layer 0 と界面の剛性比を $\Lambda=0,0.1 ， 0.2$ と変化させ， そ の他のパラメータを $N=20, \zeta=1.5, \eta=1.0$ としたときの 透過スペクトルをFig. 2(c)に示す. 3・1・2項で推察され

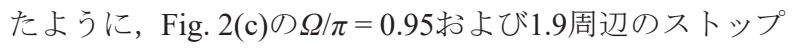
バンド発生挙動が $\Lambda$ に強く依存している.

一方で, Fig. 2(c)の $\Omega / \pi=0.5$ および 1.5 周辺には $\Lambda=0$

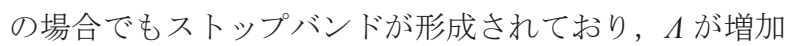
するとそれらがバンド幅や深さをほとんど変えずに低 周波数側へ移動している. $\Lambda=0(K \rightarrow \infty)$ では各界面 が完全接着状態となり，波動の反射は隣接する媒質のイ ンピーダンス差のみによって生じる.したがって, $3 \cdot 1 ・$ 2 項の結果（Fig. 2(b)）も合わせて考えると，これらのス

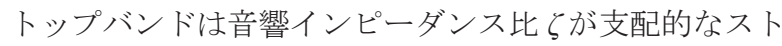
ップバンドであると結論付けられる.

$3 \cdot 1 \cdot 4$ 伝搬時間比 $\eta$ の影響 Layer 0 と Layer 1 の縦 波伝搬時間の比を $\eta=1.0,1.2,1.4$ と変化させ，その他の パラメータを $N=20, \Lambda=0.1, \zeta=1.5$ としたときの透過ス ペクトルをFig. 2(d)に示す.

式(16)および(17)からわかるように個々の界面におけ る反射・透過挙動は $\eta$ に依存しないが，Fig. 2(d)ではスト ップバンド発生周波数が $\eta$ に依存している。これは，各 媒質内の波動伝搬時間が変化することで，各界面からの 反射波の位相差が変化（位相整合条件を満たす周波数が 変化）するためである。

\section{$3 \cdot 2$ 二次高調波振幅の周波数依存性}

$3 \cdot 1$ 節の結果に基づいて，本節では反射波・透過波に 含まれる二次高調波振幅（式(36)および(37)）の周波数依 存性について検討する.

ここでは, 積層構造のある特定の界面にのみ閉口欠陥 が生じている状況を想定し， $x=X_{\mathrm{s}}(1 \leq s \leq N)$ に位置す る界面だけが非線形性 $\beta_{s}=\beta>0$ を有している場合（そ の他の界面では, 久陥が存在せず $\beta_{m}=0$ と仮定）の二次 
高調波伝搬挙動を考える. 界面数を $N=20$, 剛性比を $\Lambda=$ 0.1 ，インピーダンス比を $\zeta=1.5$, 伝搬時間比を $\eta=1.0$, 非線形パラメータを $\beta=1 \times 10^{6} \mathrm{~m}^{-1}$, 入射振幅を $A_{\text {in }}=10$ $\mathrm{nm}\left(\beta A_{\text {in }}=0.01\right)$ とし, 非線形界面の位置を $s=2,10$, 19 と変化させたときの反射波・透過波に含まれる二次高 調波振幅と規格化基本周波数の関係を Fig. 3 に示す.

なお， $2 \cdot 3$ 節および $2 \cdot 4$ 節より $A_{\mathrm{R} 2} \sim \beta A_{\mathrm{in}}^{2}$ よび $A_{\mathrm{T} 2} \sim \beta A_{\mathrm{in}}^{2}$ となるため, Fig. 3 の縦軸は入射波振幅および 非線形パラメータの大きさに依存しない量である。また, Fig. 3(a)には, 1 次元動的有限要素解析で求めた透過波の 二次高調波振幅も合わせて示している. 式(37)から求め た值が数值解析で得られた結果と良好に一致しており, 第 2 章の摂動解析の妥当性を確認することができる.

Fig. 3 を見ると，反射波および透過波に含まれる二次 高調波振幅は複雑な周波数依存性を示しており，さらに 積層構造中の非線形界面の位置にも依存している。これ らの結果を解釈するために，以下ではいくつかの代表的 な周波数に着目し，界面間隙幅および変位の空間分布を 用いて Fig. 3 を考察する. なお，Fig. 3 に対応する基本 波の伝搬特性は Fig. 2(a)（実線）に既に示してある。

$3 \cdot 2 \cdot 1 \Omega / \pi=0.7$ 近傍 Fig. 3 の $\Omega / \pi=0.7$ における 積層構造内部の基本波の変位場 $\left|U_{1}(x)\right|$ と二次高調波の 変位場 $\left|U_{2}(x)\right|$ を Fig. 4 に示す。なお Fig. 4 では隣接層の 厚さの比を $h_{1} / h_{0}=2$ としている.

Fig. 2(a)より $\Omega / \pi=0.7$ のとき基本波はパスバンドに属
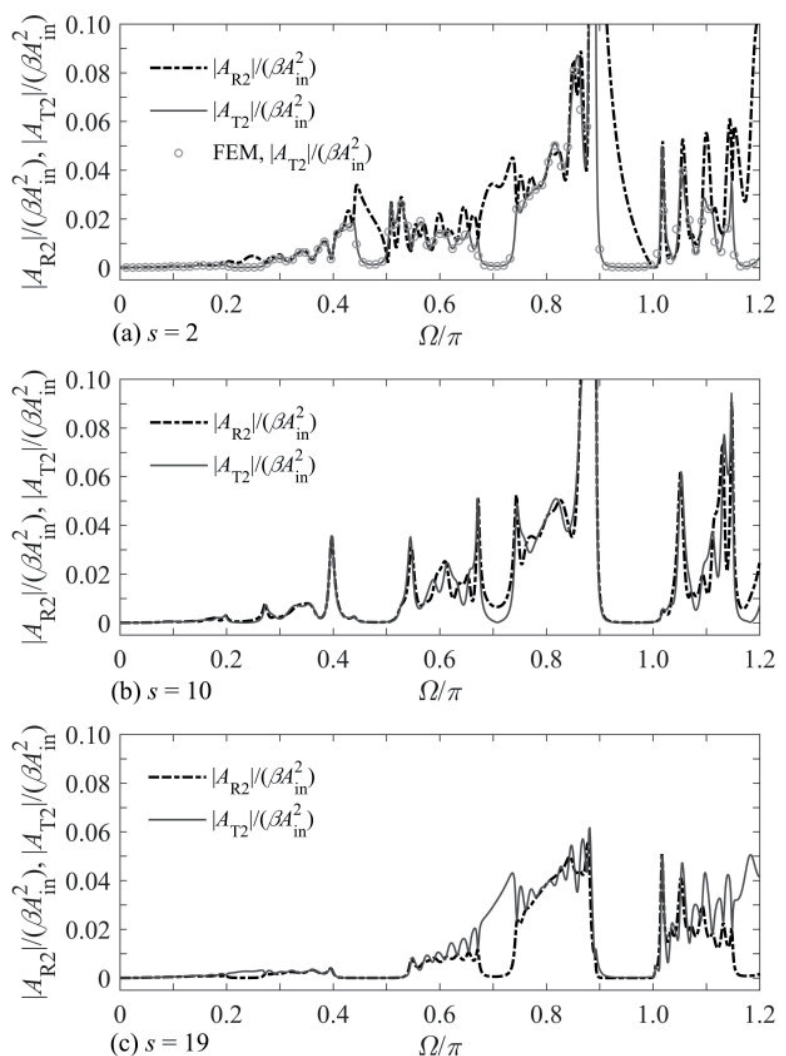

Fig. 3 Frequency dependence of the second-harmonic amplitudes of the reflected and transmitted waves due to a single nonlinear interface for $N=20, \Lambda=0.1, \zeta=1.5$ and $\eta=1.0$. The nonlinear interface is located at (a) $x=X_{2}$, (b) $x=X_{10}$ and (c) $x=X_{19}$.
しており，積層構造中を伝搬することができる，そのた め, Fig. 5 に示すように $\Omega / \pi=0.7$ における非線形界面の 間隙幅は，どの界面でもほぼ同じ大きさとなる。したが って，非線形界面における二次高調波の駆動力は - $\beta_{S} K Y_{1 s}^{2} / 2$ で表されることから，非線形界面の位置に依 らず二次高調波発生量もほぼ同等となる。

次に，非線形界面で発生した二次高調波は積層構造中 を線形に伝搬するため，その伝搬特性はおよそ $T(2 \Omega)$ に よって支配される。そこで，Fig. 2(a)を見ると，基本波 の二倍周波数 $(\Omega / \pi=0.7 \times 2=1.4)$ がストップバンドに 属している. そのため, Figs. 4(b)-4(d)に示すように，二 次高調波は非線形界面から離れるにつれて徐々に減衰

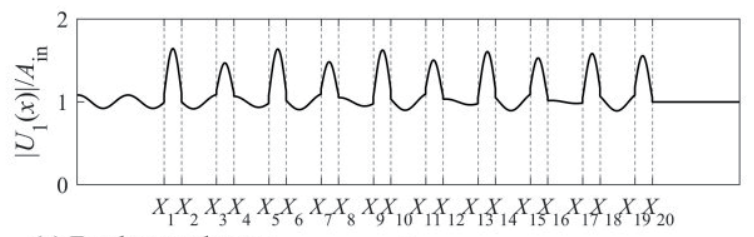

(a) Fundamental wave

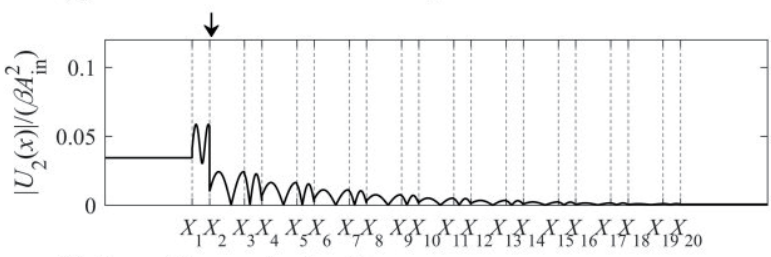

(b) Second harmonics $(s=2) \quad x$

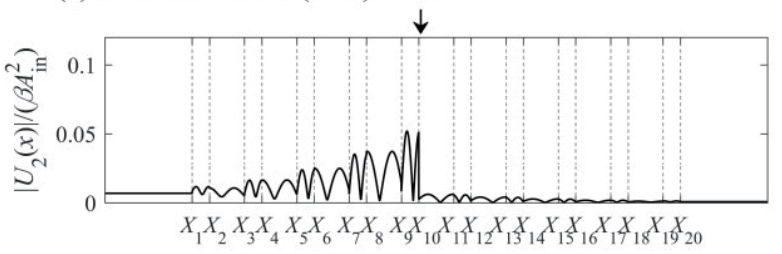

(c) Second harmonics $(s=10) \quad x$

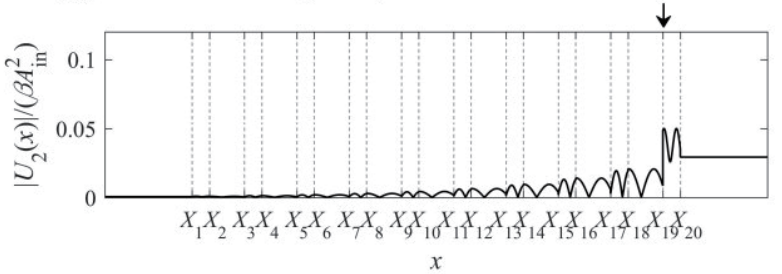

(d) Second harmonics $(s=19)$

Fig. 4 Spatial distribution of fundamental and second-harmonic displacements due to a single nonlinear interface when $N=20$, $\Lambda=0.1, \zeta=1.5, \eta=1.0$ and $\Omega / \pi=0.7$. (a) Fundamental-frequency component. (b) ${ }^{-(d)}$ Second-harmonic components. The position of nonlinear interface is indicated by arrows in (b)-(d).

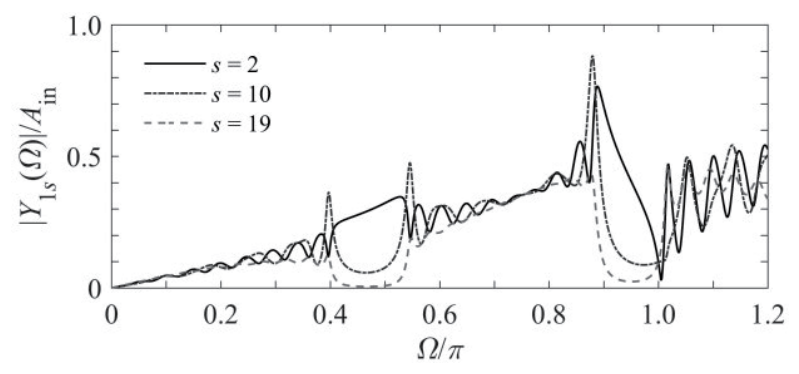

Fig. 5 Frequency dependence of jump of fundamental-frequency displacement $Y_{1 s}$ at the interfaces located at $x=X_{2}, X_{10}$ and $X_{19}$. 
する.ただし，非線形界面が $x=X_{2}$ に位置するとき（Fig. 4(b)）は，そこで発生した二次高調波は積層構造の影響 をほぼ受けることなく反射側 $\left(x<X_{1}\right)$ に到達する. 同 様に非線形界面が $x=X_{19}$ に位置するとき (Fig. 4(d)) は, 二次高調波がほぼ直接透過側 $\left(x>X_{20}\right)$ 一到達する.

上記の理由から, Fig. 3 の $\Omega / \pi=0.7$ 近傍では, Fig. 3(a) の反射波および Fig. 3(c)の透過波を除いて, 二次高調波 成分がほぼ含まれない周波数帯が形成される. Fig. 3 の $\Omega / \pi=0.25$ や 1.2 近傍についても同様である.

$3 \cdot 2 \cdot 2 \Omega / \pi=0.95$ 近傍 次に, Fig. $3 \omega \Omega / \pi=0.95$ における積層構造内部の基本波の変位場 $\left|U_{1}(x)\right|$ と二次 高調波の変位場 $\left|U_{2}(x)\right|$ を Fig. 6 に示寸.

Fig. 2(a)より $\Omega / \pi=0.95$ のとき基本波はストップバン ドに属しており，振幅透過率は $T(\Omega)=$ 約 0.05 と低くな る. そのため, Fig. 6(a)では基本波が積層構造の左端から 右端にかけて徐々に減衰し, 非線形界面が右端に近いほ ど間隙幅が低下する（Fig. 5 の $\Omega / \pi=0.95 ）$.これより， 非線形界面が $x=X_{19}$ に位置するとき（Fig. 6(d)）の二次 高調波発生量は $x=X_{2}$ の場合 (Fig. 6(b)) に比べて小さく なる.また, Fig. 2(a)より基本波の二倍周波数 $(\Omega / \pi=1.9)$ はストップバンドに属しており, 二次高調波は積層構造 中を伝搬できない.

したがって, Fig. 3 の $\Omega / \pi=0.95$ 近傍では, Fig. 3(a)の 反射波を除いて，二次高調波成分がほとんど含まれない. Fig. 3 の $\Omega / \pi=0.48$ 近傍についても同様である.

$3 \cdot 2 \cdot 3 \Omega / \pi=1.1$ 近傍 前項と同様に, Fig. 3 の $\Omega / \pi$

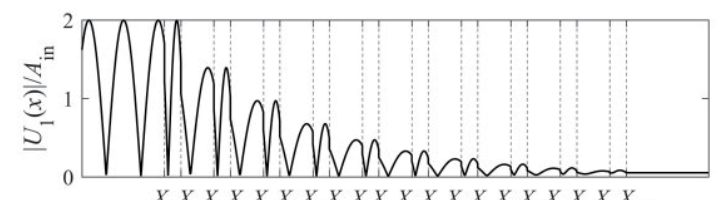

$X_{1} X_{2} X_{3} X_{4} X_{5} X_{6} X_{7} X_{8} X_{9} X_{10} X_{11} X_{12} X_{13} X_{14} X_{15} X_{16} X_{1} X_{18} X_{19} X_{20}$

(a) Fundamental wave

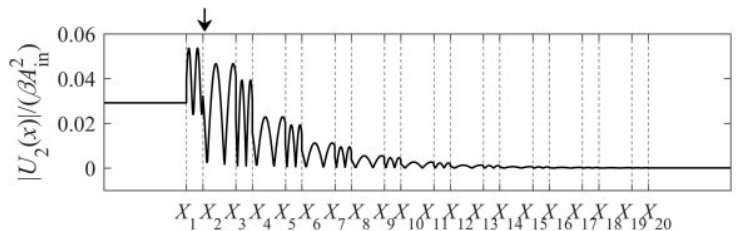

(b) Second harmonics $(s=2) \quad x$

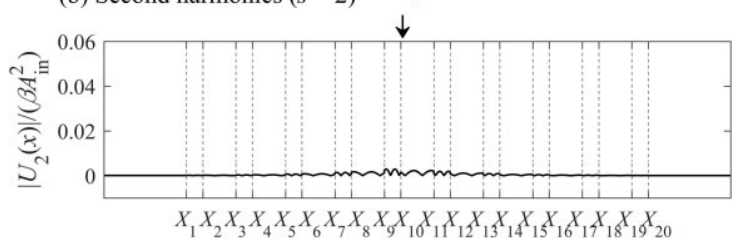

(c) Second harmonics $(s=10) \quad x$

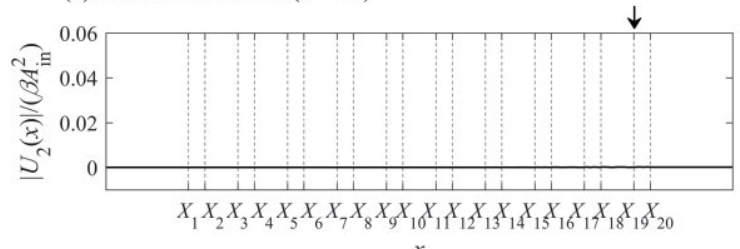

(d) Second harmonics $(s=19)$

Fig. 6 Same as Fig. 4, but for different fundamental frequency of $\Omega / \pi=0.95$.
$=1.1$ における基本波および二次高調波の変位場を Fig. 7 に示す.

Fig. 2(a)より基本波周波数（ $\Omega / \pi=1.1 ）$ および二倍周波 数 $(\Omega / \pi=2.2)$ はどちらもパスバンドに属している. そ のため, 非線形界面の位置に依らずほぼ同等の二次高調 波が発生し, それらが減衰せずに積層構造中を伝搬する. したがって, Fig. 3 の $\Omega / \pi=1.1$ 近傍では, 反射波および 透過波ともに二次高調波振幅が比較的大きくなる. Fig. 3 の $\Omega / \pi=0.6$ や 0.8 近傍についても同様である.

以上のように, 基本波および二次高調波が積層構造の 有するバンド構造の影響を強く受けるため, 反射波およ び透過波に含まれる二次高調波振幅が複雑な周波数依 存性を示す。

最後に, $N=20$ および $s=10$ のときの透過波に含まれ る二次高調波振幅の周波数依存性に関して, 無次元パラ メータ $\zeta, \Lambda, \eta$ のそぞれを変化させたときの結果を Fig. 8 にまとめて示す. Fig. 8 より, $\zeta, \Lambda, \eta$ の変化に伴い, 二次高調波振幅の周波数依存性も複雑に変化している ことがわかる. これらの傾向は， $3 \cdot 2 \cdot 1 \sim 3 \cdot 2 \cdot 3$ 項 と同様に, 積層構造のバンド構造 (Fig. 2) に着目するこ とで説明できる. なお, Fig. 8(b)の $\Lambda=0$ (完全接着状態) の場合は界面に空隙が生じない $\left(Y_{1 s}=0\right)$ ため, 二次高 調波は発生しない.

実験においても二次高調波成分の周波数依存性を測 定し, それを Fig. 3 や Fig. 8 と比較すれば, 閉口欠陥の 発生位置を同定できると考えられる。 また, 二次高調波

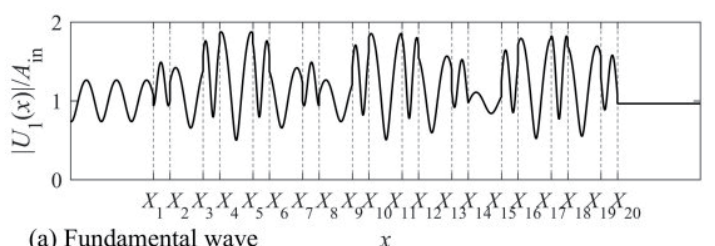

(a) Fundamental wave

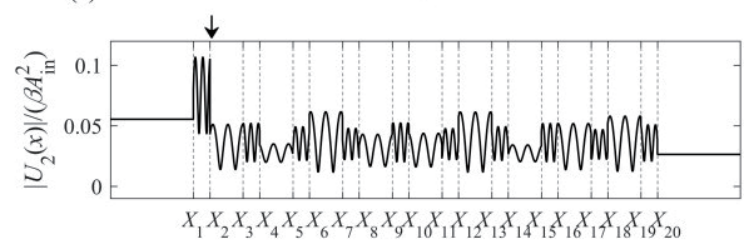

(b) Second harmonics $(s=2) \quad x$

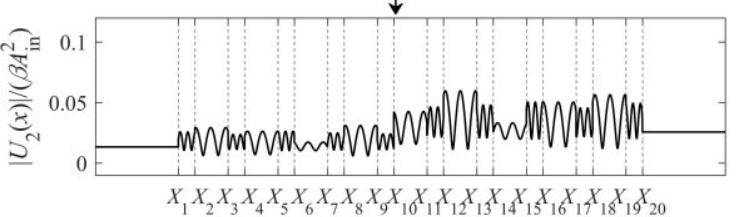

(c) Second harmonics $(s=10) \quad x$

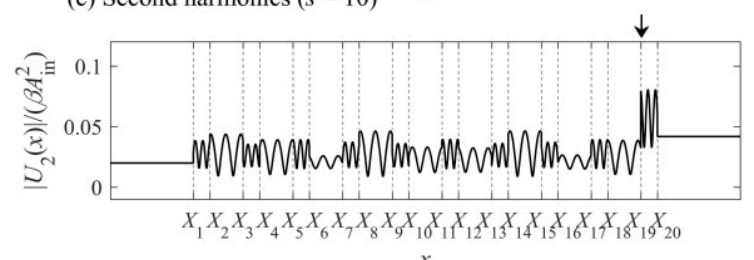

(d) Second harmonics $(s=19)$

Fig. 7 Same as Figs. 4 and 6, but for different fundamental frequency of $\Omega / \pi=1.1$. 


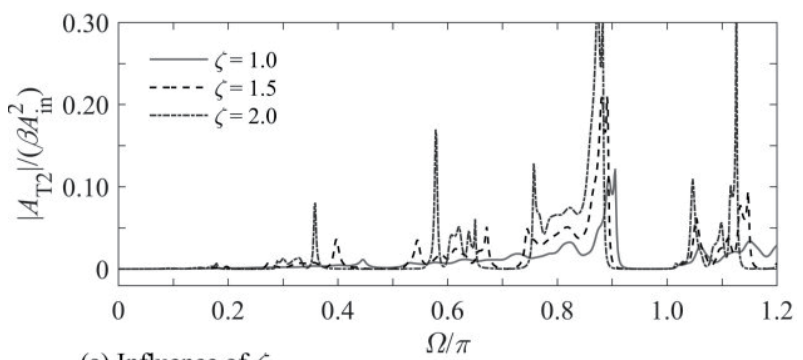

(a) Influence of $\zeta$

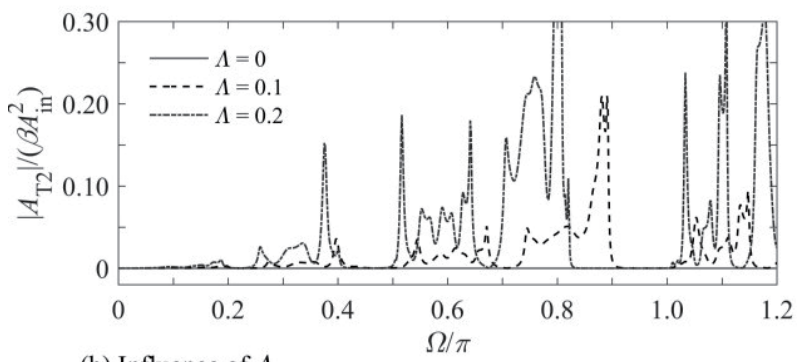

(b) Influence of $\Lambda$

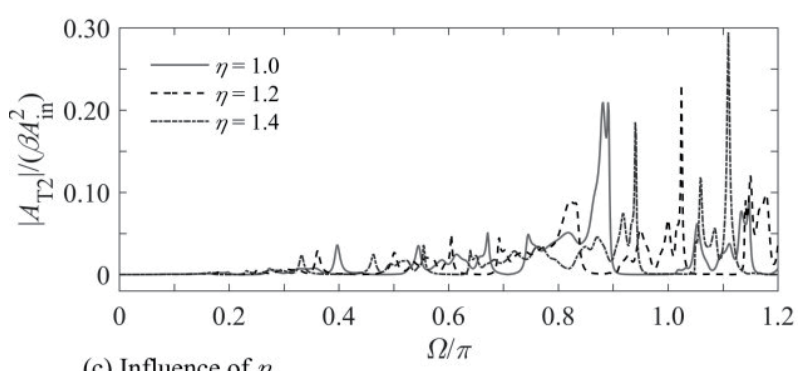

(c) Influence of $\eta$

Fig. 8 Frequency dependence of the second-harmonic amplitude of the transmitted wave due to a single nonlinear interface located at $x=X_{10}$. (a) Influence of $\zeta$ when $N=20, \Lambda=0.1$ and $\eta=1.0$. (b) Influence of $\Lambda$ when $N=20, \zeta=1.5$ and $\eta=1.0$. (c) Influence of $\eta$ when $N=20, \Lambda=0.1$ and $\zeta=1.5$.

振幅を定量的に測定することができれば, Fig. 3 や Fig. 8 の縦軸と比較して非線形パラメータ $\beta$ を求めることで, 閉口欠陥の部分接触状態（閉口状態）も評価できる可能 性がある。

\section{4 結 言}

本研究では，非線形スプリング界面を有する交互積層 構造における二次高調波発生挙動の解明および閉口欠陥 の非破壊検出のための知見を得ることを目的として，非 線形性による寄与が十分小さい仮定の下で摂動法と伝達 マトリクス法を用いた理論的検討を行った。得られた知 見を以下に記す。

1. 交互積層構造中の積層方向への波動伝搬は，規格化 周波数 $\Omega$, 界面数 $N$, 隣接する媒質の音響インピー ダンス比 $\zeta$, 界面と媒質の剛性比 $\Lambda$, 隣接する層の波 動伝搬時間比 $\eta$ の 5 個の無次元パラメータによって 支配される.

2. 積層構造のバンド構造 (周波数スペクトル) は $N, \zeta$, $\Lambda, \eta$ に依存し， $\Lambda$ が支配的なストップバンドと 支配的なストップバンドが存在する.

3. 反射波や透過波に含まれる二次高調波振幅は積層構 造のバンド構造を反映した周波数依存性を示す。ま
た，二次高調波振幅が非線形界面の位置に強く依存 する周波数帯が存在する.

実験において基本波の透過スペクトル（または反射ス ペクトル）を測定し，理論值（Fig. 2）と比較・最適化す れば，無次元パラメータ $N, \zeta ， \Lambda ＼eta$ を評価できると考え られる. そして, 同定したパラメータに基づいて理論的 に求めた二次高調波成分の周波数依存性 (Fig. 3 やFig. 8) と実測值の比較を行えば，層間に発生した閉口欠陥を非 破壊検出できる可能性がある. 特に, 非線形界面の位置 の影響が顕著に現れる周波数帯（Fig. 3 の $\Omega / \pi=0.7$ など） における二次高調波振幅に着目すれば, 閉口欠陥の有無 のみならずその位置同定も可能であると考えられる。

また，実際の交互積層構造では各層に厚さのばらつき やうねりが生じると予想される。このような厚さの不均 一性や各界面の非平行性が二次高調波発生挙動に与える 影響の解明が今後の課題として挙げられる.

\section{参 考 文 献}

1) T. E. Preuss and G. Clark, "Use of time-of-flight C-scanning for assessment of impact damage in composites", Composites, Vol.19, No.2, pp.145-148 (1988).

2) J. M. Richardson, "Harmonic generation at an unbonded interface, I. Planar interface between semi-infinite elastic media", International Journal of Engineering Science, Vol.17, No.1, pp.73-85 (1979).

3) A. M. Sutin and V. E. Nazarov, "Nonlinear acoustic methods of crack diagnostics", Radiophysics and Quantum Electronics, Vol.38, Nos.3-4, pp.109-120 (1995).

4) S. Biwa, S. Nakajima and N. Ohno, "On the acoustic nonlinearity of solid-solid contact with pressure-dependent interface stiffness", Journal of Applied Mechanics, Vol.71, No.4, pp.508-515 (2004)

5) O. Buck, W. L. Morris and J. M. Richardson, "Acoustic harmonic generation at unbonded interfaces and fatigue cracks", Applied Physics Letters, Vol.33, No.5, pp.371-373 (1978).

6) C. J. Brotherhood, B. W. Drinkwater and S. Dixon, "The detectability of kissing bonds in adhesive joints using ultrasonic techniques", Ultrasonics, Vol.41, No.7, pp.521-529 (2003).

7) S. Biwa, S. Hiraiwa and E. Matsumoto, "Experimental and theoretical study of harmonic generation at contacting interface", Ultrasonics, Vol.44, pp.e1319-e1322 (2006).

8) D. Yan, S. A. Neild and B. W. Drinkwater, "Modelling and measurement of the nonlinear behaviour of kissing bonds in adhesive joints, NDT\&E International, Vol.47, pp.18-25 (2012).

9) Y. Ishii and S. Biwa, "Acoustic harmonic generation in a multilayered structure with nonlinear interfaces", AIP Conference Proceedings, Vol.1474, pp.223-226 (2012).

10) S. Biwa and Y. Ishii, "Second-harmonic generation in an infinite layered structure with nonlinear spring-type interfaces", Wave Motion, Vol.63, pp.55-67 (2016).

11) Y. Ishii, S. Biwa and T. Adachi, "Second-harmonic generation in a multilayered structure with nonlinear spring-type interfaces embedded between two semi-infinite media", Wave Motion, Vol.76, pp.28-41 (2018).

12) W. T. Thomson, "Transmission of elastic waves through a stratified solid medium", Journal of Applied Physics, Vol.21, No.2, pp.89-93 (1950). 